\title{
Treatment of cyanide wastes through bioremediation
}

\section{Alma Deloya-Martínez ${ }^{1}$}

Deloya-Martínez, A. Treatment of cyanide wastes through bioremediation. Tecnología en Marcha. Edición especial inglés. Febrero 2016. Pág 33-46.

Original version published in spanish. Deloya, A. Tratamiento de desechos del cianuro por biorremediación. Tecnología en Marcha. Vol. 25, No 2. Abril-Junio 2012. Pág 61-72.

1 Alma Deloya M. Msc, Project Coordinator, Dept. Of Chemistry, Research Center For Environmental Protection. Instituto Tecnológico de Costa Rica. Costa Rica. Email: adeloya@Itcr.ac.cr 
Tecnología en Marcha,

34 Edición especial inglés. Febrero 2016

\section{Key words}

Autochthonous microorganisms; protective medium; lyophilization (lyophilization); leaching; microorganism consortium; bioremediation.

\section{Abstract}

This document presents results of research in which an autochthonous consortium of cyanidedegrading microorganisms was developed for use in the biological treatment of hazardous cyanide waste.

These autochthonous microorganisms were lyophilized (freeze dried) in different protective media, such as gelatin and lactose broth, at different temperatures $\left(-35,-45,-55\right.$ and $\left.-65{ }^{\circ} \mathrm{C}\right)$.

The preliminary treatment of cyanide wastes involved pretreatment of sludge for 3-5 days to leach the waste, and a subsequent treatment in aerated lagoons, where the consortium of lyophilized microorganisms was applied.

Eight different lyophilized samples were obtained at different temperatures using two protective media for lyophilization, which produced excellent results six months after lyophilization.

The consortium of lyophilized microorganisms showed $70 \%$ to $80 \%$ viability, with cyanide extraction percentages higher than 95\%, and can be kept active for long periods of time (for years).

Lyophilized microorganisms can be used for biodegradation of cyanide wastes from gold mines or from any other cyanide waste such as that from metallic electroplating baths, or from the jewelry manufacturing industry.

\section{Introduction}

Cyanide wastes are currently treated using very efficient chemical methods. However, the search for biological remedial technologies to degrade cyanide which do not generate toxic products and have a lesser impact on the environment has triggered research to replace conventional methods such as absorption, chemical conversion and electrolytic treatment. These are costly and corrosive, and generate wastes that sometimes cause more contamination than the original wastes.

This project is aimed at adapting technology that is more environmentally friendly, such as bioremediation.

One of the advantages of treating toxic waste through bioremediation is that it is less costly, since it does not require chemical reagents which require appropriate handling, and in most cases are highly expensive. In addition, bioremediation is a simple method which does not require expert staff to manage and operate the treatment system.

Bioremediation causes less negative environmental impacts. It is based on the action of autochthonous microorganisms and environmental modifications which are extremely simple, such as the addition of nutrients and aeration.

Since cyanide is a biodegradable substance, its wastes may be treated through bioremediation, because the culturing and growth of microorganisms will not be inhibited by high concentrations if the waste is prepared with a pre-treatment such as leaching (shaking and lyophilization in water). 
During bioremediation, cyanide is converted into other more stable and less toxic chemical substances through natural physical, chemical and biological processes.

Different factors affect the bioremediation process. Among the most important for cyanide bioremediation in a liquid medium are $\mathrm{pH}$, oxygen, and the concentration of cyanide.

Through this research a consortium of autochthonous cyanide-degrading microorganisms was developed to be used in the biological treatment of cyanide wastes (bioremediation). The preliminary treatment consisted in waste leaching, and a subsequent aerobic treatment in aerated lagoons with a $\mathrm{pH}$ of no lower than 9.4.

\section{Description of the problem}

Disposing of cyanide industrial liquid wastes into the environment without any treatment exceeds the powers of recuperation of the bodies or soil where they are deposited, and causes pollution and severe environmental impact, destroying ecosystems and affecting the health of nearby populations.

Treatment of pollutants in water results in protecting the environment and people's health, as well as complying with waste disposal specifications included in regulation 33601 MINSALUDMINAE, which is in force in Costa Rica.

In general, cyanide waste has been treated with costly chemical methods using chemical substances that entail major investments and adequate dosage and handling.

This is the case with the effluents from cyanide-intensive processes. For instance, the process to obtain precious gold and silver from fields of intrusive rocks in quartz beds produces collateral reactions with minerals associated with the gold or silver which are quite complex and toxic.

In addition, the Materials Engineering Laboratory of the Instituto Tecnológico de Costa Rica generates wastes from the nitriding of metals that can be treated through biodegradation, applying the consortium of cyanide-degrading microorganisms produced through this research.

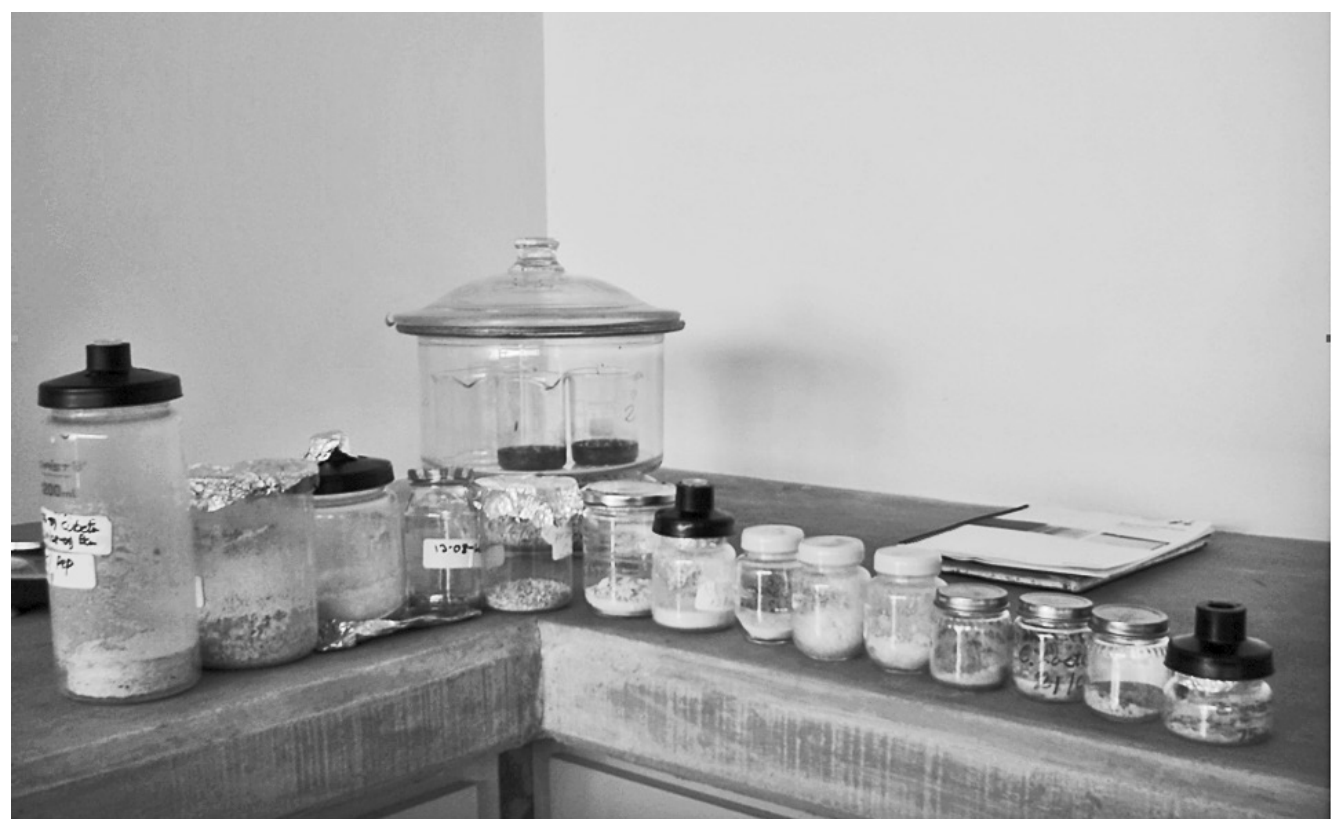

Figure 1. Consortium of lyophilized microorganisms in different temperatures, before 10 months of preservation. 


\section{General objective}

Develop a consortium of microorganisms adapted for degrading high concentrations of cyanide, which can be kept for long periods of time and be used in bioremediation of hazardous cyanide wastes.

\section{Specific objectives}

- Apply preliminary treatment of the waste for leaching and detoxification of cyanide wastes.

- Obtain an enzymatic or microbial extract through a selective substrate, for use in cyanide waste bioremediation.

- Lyophilization the extract obtained to preserve it and have it available over long periods of time (years).

\section{Materials and methods}

A consortium of microorganisms was obtained from cyanide waste generated during the nitriding ${ }^{2+}$ process at the Materials Engineering Laboratory of the Instituto Tecnológico de Costa Rica, in Cartago.

\section{Main equipment}

- Cyanide content in wastes was measured with the LaMotte SMART Spectro portable spectrophotometer.

- The level of dissolved oxygen was determined with a Fischer Scientific APG4 portable measuring device with a membrane electrode.

- $\mathrm{pH}$ control during cyanide waste treatment was measured with a Denver UB-10 table-top instrumental $\mathrm{pH}$ meter.

- Microscopic observations were made with a MOTIC Trinocular Microscope, model BA300.

- To separate the microorganism extract to be lyophilized, we used a Damon centrifuge and EC Division and EC- HN-FII, model dcs-16rv-r.

- The bacteriological media) were sterilized in a life sciences C-7511 autoclave.

- A Thermo Electron Corporation Precision stove was used to determine the residual moisture of the lyophilized preparation.

2 + Liquid nitriding is performed in a molten salt bath typically consisting of a mix of sodium and potassium salts. The sodium salts, which comprise 60 to $70 \%$ (by weight) of the total mixture, consist of $96.5 \% \mathrm{NaCN}, 2.5 \% \mathrm{Na} 2 \mathrm{CO} 3$, and $0.5 \%$ $\mathrm{NaCNO}$. Liquid nitriding is one of the thermal treatments used primarily to improve metal surface hardness and corrosion resistance; it is one of the least costly treatments and requires less equipment than other treatments. 


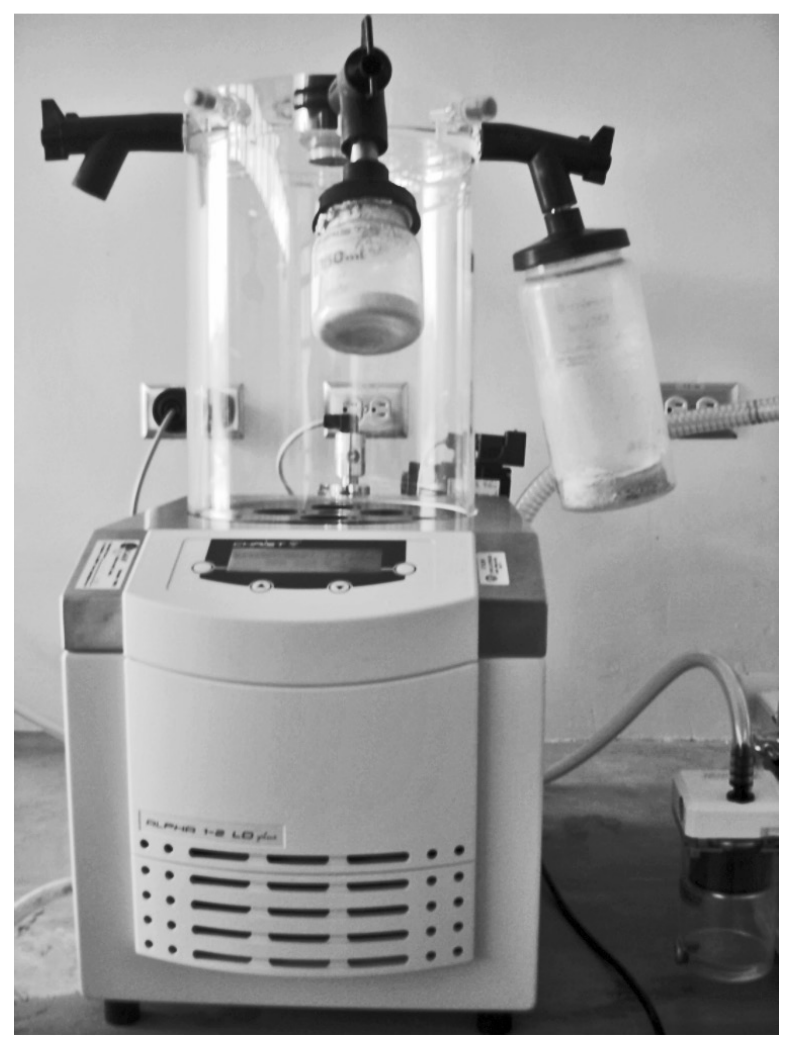

Figure 2. ALPHA 2-4 / LD Freeze Dryer used in the study.

\section{Methodology}

The cyanide content of the waste studied was determined using the 36-SC cyanide method of the portable LaMotte SMART Spectro spectophotometer.

To obtain the cyanide-degrading consortium, first the waste was leached in water at room temperature with calcium, iron and magnesium micronutrients, agitating the solution for 3 days, and ensuring that the $\mathrm{pH}$ was always equal to or above 10.4 to obtain an alkaline medium. In addition, controls were implemented to keep dissolved oxygen at least at $2 \mathrm{mg} / \mathrm{L}$, to ensure aerobic conditions (1) (2).

The second step to obtain the cyanide-degrading microorganism consortium was to extend the previous 3-day period of agitation of the solution to a period of 63-72 days, under the previously indicated conditions, feeding every other day during the trial period with $1.4 \mathrm{mg} / \mathrm{L}$ of cyanide waste as the only source of carbon and nitrogen for the bacteria (3).

All the leaching and biodegradation trials were triply replicated in 25-liter containers, each containing a treated waste volume of 20 liters.

During the process of obtaining the microorganism consortium, the control trials were: $\mathrm{pH}$, dissolved oxygen, temperature, and microscopic tests. All analyses were carried out according to standardized methods for water and residual water analysis (4).

To select and adapt the microorganism consortiums, they were separated by spinning at 5000 rpm for 10 minutes, then washed with distilled water twice and incubated for 48 hours at room temperature, in lactose broth at $20 \%$. Micronutrients were added, and cyanide concentration was 
gradually increased from 1400 to $2500 \mathrm{mg} / \mathrm{L}$. Trials were carried out under aerobic conditions, keeping dissolved oxygen at least at $2 \mathrm{mg} / \mathrm{L}$ and $\mathrm{pH}$ between 9.4 and $10.4 \mathrm{pH}$ units (1).

This process for selecting and adapting microorganisms was carried out up to the third generation of microorganisms, re-injecting microorganisms separated through spinning at 5000 rpm in lactose broth, under the same previous conditions of nutrients, oxygen and $\mathrm{pH}$.

In every case, growth of microorganisms was controlled with microscopic observations every second day. The new strains obtained were separated again through spinning and were frozen for later lyophilization.

The microorganism consortiums, separated by centrifuging, were resuspended in different lyophilization protective media such as $10 \%$ and $5 \%$ gelatin, and $10 \%$ and $5 \%$ lactose broth (5).

After resuspension, microorganisms were frozen the day before lyophilization for 20-24 hours, at temperatures of from $-3^{\circ}$ to $0^{\circ}$ centigrade.

The lyophilization process was carried out under pressures of $0.250,0.070,0.021$ and 0.0054 millibars equivalent to re-sublimation temperatures of between $-35^{\circ},-45^{\circ},-55^{\circ}$ and $-65^{\circ}$ centigrade, respectively. Lyophilization times were 24-36 hours for the primary drying process. Secondary drying was carried out at $20^{\circ}$ centigrade, for $10-8$ hours (6).

The moisture level of the lyophilized preparation was determined during primary and secondary drying, to control the final moisture level of the lyophilized microorganisms.

The lyophilized microorganisms were preserved in refrigeration and at room temperature, in both cases in sealed glass jars.

Lyophilized microorganisms were recovered, re-hydrating them at room temperature, in a lactose broth suspension at $10 \%$, with a cyanide concentration of $2500 \mathrm{mg} / \mathrm{L}, \mathrm{pH}$ of 9.4 to 10.4, and dissolved oxygen concentration of no less than $2 \mathrm{mg} / \mathrm{L}$. For retrieving the lyophilized microorganisms, $10 \mathrm{ml}$ of the lyophilized culture at $0.1 \%$ of the suspension were taken, and re-suspended in $100 \mathrm{ml}$ of lactose broth at $10 \%$. The suspension of the lyophilized preparation was incubated for 48 hours at room temperature (7).

A heterotrophic recount of microorganisms was done 48 hours after retrieval, to calculate the percentage of recovery of the lyophilized organisms. This recount was carried out at the CEQIATEC Laboratory of the Department of Chemistry of the Instituto Tecnológico de Costa Rica.

Treatment of cyanide waste was replicated in triplicate. Wastes were leached in 20 liters of water, agitated for 3 days at $200 \mathrm{rpm}$. During the 3 pre-treatment days, the $\mathrm{pH}$ was kept at values equal to or higher than $10.4 \mathrm{pH}$ units. After leaching, wastes were treated by diffusers under the same $\mathrm{pH}$ conditions, dissolved oxygen and nutrients under which the microbial consortium was obtained, extending treatment time for 12 more days (9).

Cyanide level was quantified before and after the total 15-day treatment (3 days of pre-treatment by leaching, and 12 days of treatment by aeration).

\section{Project results}

The main result of this project was obtaining a microorganism consortium adapted for the treatment of high concentrations of cyanide-containing waste, able to achieve cyanide degradation through biological processes, as well as developing a biotechnological method to treat cyanide wastes in concentrations similar to those generated in gold mines, in electrolytic processes, and in the jewelry industry. 


\section{Other project results}

Other important results were obtained in this project, including the generation of a new biological technology for decontamination of toxic wastes and cyanide wastes, and training of experts in bioremediation and their integration with leading groups in issues related to environmental biotechnology and bioremediation of water at the institutional level.

Likewise, the impacts generated by the project include the potential for the Instituto Tecnológico de Costa Rica to partner with the mining industry and with technological businesses in the environmental area. Implementation of this project also entails working with a strategic research orientation in major issues related to environmental pollution and biotechnology.

The project has significant social and economic impacts. From a social point of view, having a decontaminated environment owing to this treatment that the mining and chemical industries will be able to apply to their waste waters. From an economic point of view, the most significant impact is obtaining a technological solution to treat cyanide-containing water which is financially feasible and convenient for the country's current situation. It is also possible to reach agreements for the commercialization of this technology at a national level.

\section{Project results}

The following are some of the main project results. The study was carried out at the Environmental Protection Center of the School of Chemistry of the Instituto Tecnológico de Costa Rica, between February 22, 2008 and February 22, 2010.

Table 1 presents the characteristics of the waste with respect to cyanide concentration. Table 2 shows the times in which cyanide-degrading microorganisms were obtained.

Table 1. Cyanide concentration in wastes of the Materials Sciences Laboratory, ITCR, Cartago.

\begin{tabular}{|c|c|}
\hline Sample & Concentration $(\mathrm{mg} / \mathrm{L})$ \\
\hline 1 & 1400 \\
\hline 2 & 1300 \\
\hline 3 & 1200 \\
\hline 4 & 1600 \\
\hline
\end{tabular}

Source: Deloya, A.

Table 2. Presence of microorganisms during the process of obtaining a consortium of autochthonous cyanidedegrading microorganisms

\begin{tabular}{|c|c|}
\hline Sample & Concentration $(\mathrm{mg} / \mathrm{L})$ \\
\hline 1 & 1400 \\
\hline 2 & 1300 \\
\hline 3 & 1200 \\
\hline 4 & 1600 \\
\hline
\end{tabular}

\footnotetext{
* Nutrients were added in every trial: Calcium Chloride, Iron Chloride, and Magnesium Chloride. Source: Deloya, A.
} 
Tables 3 and 4 summarize average moisture of the lyophilized preparation resulting from primary and secondary drying in the protective lyophilization media. The heterotrophic recount for obtaining the percentage of retrieval of lyophils, or viability, is shown in Table 5.

Lastly, Table 6 shows the percentage of cyanide degradation by the microbial consortium after the leaching pre-treatment and the treatment with aeration and agitation.

Table 3. Moisture of the lyophilized preparation in two protective media, after primary drying

\begin{tabular}{|c|c|c|}
\hline \multirow{2}{*}{$\begin{array}{c}\text { Lyophilized } \\
\text { preparation }\end{array}$} & Moisture of lactose broth (\%) & Moisture of gelatin (\%) \\
\cline { 2 - 3 } & 11.70 & 9.09 \\
\hline 1 & 15.80 & 9.40 \\
\hline 2 & 10.00 & 8.00 \\
\hline 3 & 12.00 & 7.40 \\
\hline 4 & 14.00 & 12.00 \\
\hline 5 & & \\
\hline
\end{tabular}

Source: Deloya, A.

Table 4. Moisture of lyophilized preparation in two protective media, after secondary drying

\begin{tabular}{|c|c|c|}
\hline \multirow{2}{*}{$\begin{array}{c}\text { Lyophilized } \\
\text { preparation }\end{array}$} & Moisture of lactose broth (\%) & Moisture of gelatin (\%) \\
\cline { 2 - 3 } & 3,89 & 1,42 \\
\hline 1 & 2,00 & 1,20 \\
\hline 2 & 5,26 & 1,35 \\
\hline 3 & 3,00 & 1,96 \\
\hline 4 & 4,30 & 1,38 \\
\hline 5 & & \\
\hline
\end{tabular}

Source: Deloya, A.

Table 5. Heterotrophic recount to determine retrieval of lyophilized preparation

\begin{tabular}{|c|c|}
\hline Sample & UFC recount / 100ml \\
\hline 1 & Before lyophilization / After lyophilization \\
\hline 2 & $5,9 \times 10^{17} 1,5 \times 10^{15}$ \\
\hline 3 & $1,2 \times 10^{17} 3,8 \times 10^{14}$ \\
\hline
\end{tabular}

Source: Deloya, A.

(t) retrieval time 48 hours

Trial volume - 20 liters $\mathrm{pH} \mathrm{10,4}$ units 
Table 6. Percentage of cyanide degradation according to selected variables $\left(^{*}\right)$

\begin{tabular}{|c|c|c|c|}
\hline Trial & $\begin{array}{c}\text { Concentration Initial } \\
\text { cyanide }(\mathrm{mg} / \mathrm{L})\end{array}$ & $\begin{array}{c}\text { Concentration Final } \\
\text { cyanide }(\mathrm{mg} / \mathrm{L})\end{array}$ & Extraction (\%) \\
\hline 1 & 3600 & 2,58 & 99.9 \\
\hline 2 & 1920 & 2,21 & 99,8 \\
\hline 3 & 1440 & 1,65 & 99,8 \\
\hline
\end{tabular}

Source: Deloya, A.

\section{Discussion of results}

Descriptions of wastes in different lots of the samples indicate total cyanide concentrations of $1400 \mathrm{mg} / \mathrm{L}, 1300 \mathrm{mg} / \mathrm{L}, 1200 \mathrm{mg} / \mathrm{L}$, and $1600 \mathrm{mg} / \mathrm{L} ;$ see Table 1.

The $\mathrm{pH}$ of the waste during the trials ranged from 9.48 to $11.40 \mathrm{pH}$ units. This parameter as an inherent characteristic of cyanide waste was an advantage and one of the most important factors during treatment by biodegradation of the waste, since in literature it is mentioned that $\mathrm{pH}$ alkaline values improve cyanide degradation (9).

Cyanide may be present in two forms, depending on the $\mathrm{pH}$ of the medium in which it is found. With an alkaline $\mathrm{pH}$ the soluble form of cyanide prevails, while with a neutral $\mathrm{pH}$ and acid in the medium, the gaseous form prevails - hydrocyanic acid (10).

Based on the above, $\mathrm{pH}$ values were kept between 9.16 and 10.4 during the cyanide biodegradation treatment. This is vitally important for cyanide to remain dissolved so that it does not pass to the environment as gaseous hydrogen cyanide. This gas acts in a few seconds in the respiratory system, inhibiting respiratory enzymes such as cytochrome oxidase (11).

During the leaching treatment process, solid cyanide was extracted by agitation using water as a solvent. When cyanide comes into contact with water by agitation it diffuses to the liquid phase - solid cyanide goes to the liquid phase. This preliminary process in the cyanide biodegradation process is also known as cyanide leaching (2).

Agitation to maintain contact between waste and water proved to be key for waste biodegradation since it allows cyanide leaching by water (12).

The development and harvesting of native cyanide-degrading microorganisms was achieved over very long periods of time. The first microorganisms were obtained on day 72 in the first trial; in the second replication on day 66, in the third replication on day 63, and on the last trial on day 60 (see Table 2). This prolonged time to obtain autochthonous cyanide-degrading microorganisms in the different trial reagents matches the prolonged times necessary to obtain them in other investigations for mining wastes (7).

Recent studies reveal that cyanide toxicity consists of inhibiting microorganism respiration. This is possibly the reason why cyanide-degrading microorganisms need a prolonged time for their development (13).

Cyanide-degrading microorganisms have specific enzymatic systems which allow them to grow in environments with a high cyanide concentration. During biodegradation, cyanide hydratase converts cyanide into formamide, which is finally converted into carbon dioxide $\left(\mathrm{CO}_{2}\right)$ and ammonia $\left(\mathrm{NH}_{3}\right)$. Other enzymes such as beta-cyanoalanine and cyanide monoamine oxidase 
may also biodegrade cyanide into other simpler, non-polluting substances. In addition, some bacteria transform cyanide directly into $\mathrm{CO}_{2}$ and $\mathrm{NH}_{4}$ through the cyanide dioxygenase enzime, without forming intermediary products (14).

The ability of microorganisms to use cyanide compounds as a source of carbon and nitrogen was used for growing, obtaining and adapting the microbial cyanide-degrading consortium, transforming toxic cyanide wastes into non-polluting substances.

The selection of a stronger microorganism consortium, more effective at degrading cyanide, was achieved by the continuous culture method, in which dominant microorganisms were selected according to their substrate affinity. In this case, the concentration of the cyanide waste (selective substrate), increased the specific growth speed of the cyanide-degrading microorganism consortium with respect to the speed of growth of other microorganisms which may grow in the same medium (15).

Lyophilization to conserve the cyanide-degrading microorganism consortium was carried out in two stages. The first stage was one of slow freezing, with a temperature of $0^{\circ}$ to $-3^{\circ}$ centigrade for 24 hours where the water containing the microorganism extract was solidified. Freezing is key so that solutes and non-frozen water form a vitreous stage, whereby the characteristics and structure of the final lyophilized product are preserved. This structure remains fixed during this freezing stage (16).

The second lyophilization stage consisted of the sublimation of the frozen water in the extract called the primary dried material. For this stage pressures were applied during sublimation ranging from 0.0250 to 0.0054 millibars, which correspond to temperatures of $-35^{\circ}$ to $-65^{\circ} \mathrm{C}$.

The primary drying stage was carried out at the triple point of water so that it would pass directly from the solid phase to the vapor phase without passing through the liquid stage (sublimation). As a result, the initial structure of the product and its chemical and biological characteristics are preserved (16).

During the sublimation drying process $95-98 \%$ of the water in the microorganism extract was eliminated.

After primary drying by sublimation, secondary drying was carried out at $20^{\circ} \mathrm{C}$ for periods of 8-10 hours. This was done to eliminate water which remained fixed or linked by absorption during the freezing process, because the free water molecules (i.e., water not fixed to the structure of the microorganisms) were eliminated in the primary drying.

Lactose broth and gelatin were used as protective media for the bacteria during all lyophilization trials. An analysis of the influence of the protective medium in lyophilization shows that the lactose broth produced good results, but that it had a disadvantage: the final product was difficult to dissolve during recovery. This was possibly caused by the decomposition of lactose during the lyophilization process, which causes lactose to form an external impermeable layer in the lyophilized preparation that prevents a good rehydration of the product (16).

However, using gelatin as a protective medium, a final product was obtained which had excellent -virtually instantaneous- solubility.

Use of protectors is very important because lyophilization has limitations during the freezing stage, due to the formation of ice crystals that may break the cells, and in turn cause negative effects on the microorganism in the rehydration stage for its reactivation (17).

Both the gelatin and the lactose broth are highly hydrophilic protective media. Both of them protect microorganisms from damage to the cell membrane and wall. Gelatin is a non-permeable protective medium, which is absorbed in the cell surface and increases local viscosity, keeping ice in an amorphous form and avoiding mechanical damage. On the other hand, the lactose 
broth is a semi-permeable protective medium which forms a layer between the cell wall and cell membrane, protecting the cell from mechanical damage (18).

The percentage of moisture of final products for the second lyophilization stage, for both the primary and secondary drying, are summarized in Tables 4 and 5, presented in the section of Results.

As can be observed in the Tables, the lyophilized products indicate that using gelatin as a protective medium produced better results in terms of the residual percentage obtained. This indicates that this medium is very important for a lasting conservation of the product, for several years. The moisture of the final product corresponds to the residual moisture which cannot be entirely eliminated during the lyophilization process. This is because if it is eliminated, there is a chance of changing the preparation's chemical and biological characteristics (19).

As previously mentioned, the residual moisture of the lyophils is key for their conservation, and to maintain activity of microorganisms over the long term - the lower the moisture, the longer the preservation time.

On the other hand, residual moisture is necessary to maintain the activity of the microorganisms because their proteins and peptides require a certain amount of water to maintain their secondary and tertiary structure (20).

Retrieval of lyophilized microorganisms was achieved six months after preservation and storage at room temperature. Table 6 of the Results section shows the data of the heterotrophic recount, which show recovery rates higher than $70-80 \%$. According to M.D. García and F. Uruburú, it may then be concluded that lyophilization was successful (21).

During recovery of the lyophilized microorganisms it was possible to increase their survival, re-hydrating them in lactose broth and in gelatin - the same media used for initial growth of the cells. Thus, if osmotic pressure is kept high during re-hydration, the recovery takes place slowly. On the other hand, after re-hydration, cell growth is delayed for an extended period, which may be reduced if a medium with the same composition as that producing optimal growth is used -although reducing its original concentration by 25-50\% (22). The microbial consortium was therefore recovered and rehydrated in lactose broth and gelatin at $10 \%$, rather than at $20 \%$. This concentration was used for the initial growth of the consortium of microorganisms (22) (23).

Among the most important factors for obtaining such outstanding recovery percentages are (21):

- Use of protectors such as gelatin and lactose broth which protected the lyophils effectively against the drastic freezing and pressure conditions.

- Pressures used during the ice sublimation process were from 0.250-0.0054 millibars these pressure conditions slow down the sublimation process; thereby allowing for a lyophils with better recovery characteristics.

- The high cell density of the extract of the microbial consortium that was lyophilized, which was higher than $10^{10}-10^{11}$ cells $/ 100 \mathrm{ml}$, (see Table 5). Higher concentrations result in better lyophilized products with good recovery and activity capacity.

- The secondary drying level achieved which was under $2 \%$. This residual water protects the walls of the microbial cells from damages.

- Slow rehydration by reducing the concentration of the rehydration medium by $50 \%$, and not using direct rehydration in distilled water.

Results of cyanide quantification, before and after the total 15-day treatment are shown in Table 7. It may be seen that cyanide extraction was above $95 \%$ in all cases. These high cyanide extractions are obtained thanks to the process of adaptation of the consortium carried out up to 
the third generation, obtaining stronger microorganisms which were more effective at extracting cyanide (22).

The microorganism consortium proved to be highly effective for extracting cyanide in concentrations higher than those reported by Restrepo et al. in similar studies (7).

\section{Conclusions}

- The adaptation of the microbial consortium through three generations made it possible to obtain stronger microorganisms, which were more effective for extracting cyanide. Extraction effectiveness reached up to $95-98 \%$.

- The cyanide-degrading autochthonous consortium obtained proves that it extracts cyanide in an effective and cost-effective manner, with short retention times (15 days).

- The high cell density of the microbial consortium extract - more than $10^{10}-10^{11}$ cells /100 $\mathrm{ml}$ - and the slow sublimation process at pressures of 0.250 to 0.0054 millibars were the reasons for obtaining lyophils with outstanding recovery characteristics of between 70 $80 \%$.

- Cyanide concentrations extracted by the microbial consortium (2500 mg/L), are higher than those reported in similar studies (7).

- The previous leaching of cyanide wastes is vital for the treatment applying the microbial consortium.

\section{Recommendations}

Main recommendations for future projects include:

- Carrying out studies for retrieval of the lyophilized cyanide microorganisms to determine their viability at 2, 4, 8, 12,16 and 20 years.

- Keeping in contact with Infinito Gold Company to offer and commercialize the cyanidedegrading microbial consortium.

- Delivering one lyophilization workshop per year to motivate students of Environmental Engineering and Biotechnology to do graduation research projects in toxic wastes and related areas.

- Following up on the methodology for obtaining microorganisms with affinity to a substrate to obtain waste-degrading microorganisms for materials such as: lactose waste, lactose fat, petroleum wastes, septic tank sludge, and lagoons in general.

\section{Bibliography}

(1) Pavas, E \& Giraldo, C. (2005). Proceso Acoplado físico-químico y biotecnológico para el tratamiento de aguas residuales procesos Ambientales y Biotecnológicos. Universidad Colombia, ISSN 1692-0694. November, 2005. Document 38-112005.

(2) LaGrega, M; et al. (1996). Gestión de Residuos Tóxicos. Tratamiento, eliminación y recuperación de suelos. Volumen II. Mc Graw Hill. Spain.

(3) Castro, M. L \& Gonzáles, F. D. (2002). Eficiencia de la Biodegradación de Cianuro por un consorcio microbiano aislado de aguas superficiales de quebradas que alimentan el río Llaucano. Universidad Pedro Ruiz Gallo. Perú. 
(4) American Water Works Association, American Public Health Association, Water Polution Control Faderation. (1992). Métodos Normalizados para el Análisis de Aguas potables y Residuales. 19th edición. Ediciones Díaz De Santos. Spain.

(5) Voget, C. (2005). Conservación de cultivos para la biotecnología y la industria, cátedras. Química.unlp.edu.ar. Curso CABBIO, 2005. Accessed: June 15, 2010. Available at: catedras.quimica.unlp.edu.ar/ingenieriabioquimicalyll/metconsmicro.ppt.

(6) Zamora, L. M. (2003). Aislamiento, identificación y conservación de cultivos lácticos. Doctoral Thesis, Universidad de Girona. Spain.

(7) Restrepo, et al. (2006). Degradación Microbiana de Cianuro procedente de plantas de Beneficio de oro, mediante una cepa nativa de P. fluorecens. Universidad Nacional de Colombia. Instituto de Minerales, Universidad de Antioquia. Master's Degree in Environmental Engineering. Colombia.

(8) Eckenfelder, Wesley. (2000). Industrial water pollution control. USA. Mc Graw Hill.

(9) Logsdon, M. J; Kagelstein, K. \& Mudder, T. I. (2001). El Manejo del Cianuro en la Extracción de Oro. Consejo Nacional de Metales y Medio Ambiente. USA. Accessed: March 24. Available at: http://www.aage.org.ar/ manejodelcianuro.pdf.

(10) Blanco, D \& Rendueles, M. (2001). Reducción del impacto ambiental en el desarrollo de nuevos proyectos de minería de oro. Áreas Técnicas. Accessed: March 25, 2009. Available at: http://www.unizar.es/aeipro/finder/ MEDIO\%2OAMBIENTE.

(11) Guerrero, J.J. (2003). Cianuro: Degradación Biológica. Perú. Accessed: March 25, 2009. Available at: http:// www.unt.edu/resource/02cyanidefeature.htm.

(12) Logsdon, M. J. El manejo del cianuro en la extracción de oro. Accessed: May 22, 2009. Available at: http://www. aage.org.ar/manejodelcianuro.pdf.

(13) Guerrero, J. Cianuro: Toxicidad y Destrucción Biológica. Revista El ingeniero de Minas. Año X, nº 35. Perú 2003. Available at: www.unt.edu/resource/ 02cyanidefeature.htm. Accessed: October 28, 2009.

(14) Guerrero, J. (2004). Biodegradación del Cianuro. Congreso Nacional de Ciencias Ambientales. Universidad Nacional Federico Villareal, Perú.

(15) Microbiología Industrial. (1981). Selección, mantenimiento y mejoramiento de microorganismos de interés industrial. Capítulo 3. Biotechnology. Vol. 1. Microbial Fundamentals. Ed. H.J. Rehm, G. Reed, Verlag Chemie.

(16) Zamora, L. M. (2003). Aislamiento, identificación y conservación de cultivos lácticos. Doctoral Thesis, Universidad de Girona. Spain.

(17) García, M. D. y Uruburu, F. Colección Española de Cultivos Tipo (CECT). Universidad de Valencia. 46100 Burjassot (Valencia). Available at: http://catedras.quimica.unlp.edu.ar/ingenieriabioquimicalyll/seminario3.doc Accessed: February 9, 2010.

(18) Voget, C. (2005). Conservación de cultivos para la biotecnología y la industria. catedras.quimica.un/p.edu.ar. Curso CABBIO. Available at: http://catedras.quimica.unlp.edu.ar/ingenieriabioquimicalyll/metconsmicro.ppt.

(19) Freire, J.R. \& Sato, M.L. (1999). Conservación de Cultivos de Rizobios. Revista Latinoamericana de Biología. Vol.41:34-41.

(20). Fernández, A. General Information to Pharma 2. Módulo V, Liofilización: Un poco de historia. Accessed: June 13, 2010. Available at: http://personal.us.es/mfarevalo/recursos/tec_far/liofilizacion.pdf

(21) García, M. D. \& Uruburu, F. Colección Española de Cultivos Tipo (CECT). Universidad de Valencia. 46100 Burjassot (Valencia). Accessed: February 9, 2010. Available at: http://catedras.quimica.unlp.edu.ar/ingenieriabioquimicalyll/seminario3.doc.

(22) Microbiología Industrial. 1981. Selección, mantenimiento y mejoramiento de microorganismos de interés industrial. Capítulo 3. Biotechnology. Vol. 1. Microbial Fundamentals. Ed. H.J. Rehm, G. Reed, Verlag Chemie.

(23) S. Borrego et al. (2001). Comportamiento de Tres Mutantes de micobacterias productoras de precursores esteroides conservadas por liofilización. Biotechnology Microbial Fundamentals. Ed. H.J. Rehm, G. 2001, Brazil.

(24) Sepúlveda, V \& Velasco, T. Tecnologías de remediación para suelos contaminados. México: Instituto Nacional de Ecología, 2002. Accessed: May 28, 2010.

http://www2.ine.gob.mx/publicaciones/libros/372/tecnomexico.html. 
Tecnología en Marcha,

46 Edición especial inglés. Febrero 2016

(26) Tchobanoglous, G \& Burton, F. (1995). Ingeniería de Aguas Residuales: Tratamiento, Vertido y Reutilización. Tercera Edición. Madrid McGraw Hill Interamericana de España S.A, Spain. 1012 pp.

(28) División de Protección al Ambiente Humano. Reglamento de Vertido y Reuso de Aguas Residuales, decreto, № 33601-MINAE-MINSALUD, Ministerio de Salud, Costa Rica, 2007. 